\title{
Agriculture in Azerbaijan and its Development Prospects
}

\author{
RAE Aliyev ZH* \\ Institute for soil science and Agrochemistry of the Azerbaijan National Academy of Sciences, Russia
}

Submission: July 09, 2018; Published: July 26, 2018

*Corresponding author: RAE Aliyev ZH, Institute for soil science and Agrochemistry of the Azerbaijan National Academy of Sciences, Russia, email: zakirakademik@mail.ru

Abstract

This article discusses the issues of natural and economic conditions of climate, vegetation, hydrography, land cover issues of irrigated agriculture in the Republic; problems of salinity and soil erosion here. Studied agriculture in Azerbaijan state and its role in the economy of the country, where it was determined the situation of agriculture and its development, strategy and priorities of the agriculture Republic etc.

Keywords: Sustainable Erosion; Degradation of the Environment Wednesday; Resources; Arable lands

\section{Introduction}

Agriculture of the Republic of Azerbaijan is the second, after the oil industry, the largest sector of the economy of this country. So its sustainable, balanced development is the basis of improving the welfare of the people (Figure 1).

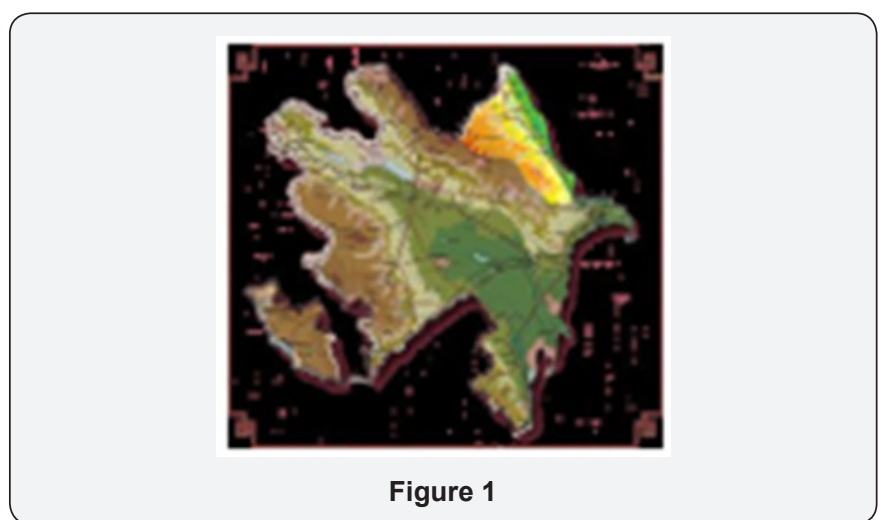

Agricultural lands occupy $50 \%$ of the total area of the country (including arable land-18.4\%, meadows and pastures-25.0\%), agriculture employs about $18 \%(2005,2011)$ the working-age population lives in rural areas and 48 per cent of the inhabitants of the Republic. Taking into account the current level of agricultural production, soil agricultural regions of Azerbaijan were subjected to intense erosion processes. More than half of Azerbaijan's territory is occupied by mountains. Steep slopes and climatic conditions favor the development of erosive processes, causing environmental degradation Wednesday, which in turn covers the entire territory, which is at risk, but intensely used in agricultural purposes. Further expected growth in agricultural production will entail strengthening the antropopresii and the even greater threat of degradation of soil resources. Hence the desire of the various methods (legal and economic mechanisms, education) to the balanced use and their protection in agricultural areas. The holding of the joint Polishwork and research on application of GIS technology to analyze factors and assess the threat of soil erosion in Azerbaijan and the results are the basis for the preparation of the scientific benefits, setting forth basic provisions on evaluation and soil anti-erosion techniques.

The Handbook presents general characteristics of natural conditions Azerbaijan and area studies. It contains information on the factors contributing to the development of erosion. On this basis, represented by agri-environmental peculiarity of eroded soils, their classification and mapping in Azerbaijan. The database created and collected in it have been applied to different spatial analyses for individual parameters of the terrain, soil structure and soil sustainability assessment to the leachate may run off. The figures used to perform GIS technology maps threat from erosion and spatial characteristics of herbaceous formations and pohotnik land on site research. A large part of the manual is devoted to methods of protection of soil from erosion. It presents different types of soil conservation activities of green and arable land for their application, as well as to set out briefly the question of protection of water related to erosive processes. A significant problem with erosion-preventive protection of the soil, is to increase the fertility of winter pastures, which create a dense grass. In arid mountainous areas of great importance is the use of irrigation technologies, limiting soil washout. Achievements in this area are described in the 
below materials that will facilitate the use of GIS technology for studying and recording the erosion phenomena in other regions of Azerbaijan, and expansion among agronomists and erosion control professionals knowledge and anti-erosion measures on soil conservation.

\section{Natural and Economic Conditions of Azerbaijan}

Square of the Republic of Azerbaijan-86.6 thousand $\mathrm{km}^{2}$, the population (January 1, 2018)-over 10.0 million. man. Azerbaijan is situated on the western shore of the Caspian Sea. The length of the coast of the Caspian Sea in Azerbaijan is $713 \mathrm{~km}$. Azerbaijan is an important transportation hub of Commerce and of the "Great Silk Road" (Figure 2). Azerbaijan occupies the North-Western and South-Eastern parts of the Caucasian Ridge. The borders of the Republic of are: Republic of Daghestan in the North, part of the Russian Federation, with the West-Armenian and Georgian Republic, East-Caspian Sea, to the South it borders (c) Iran and Turkey. the territory is divided into 5 major natural-economic zones: greater and Lesser Caucasus, Lenkoran and zone located between them extensive Kura-Aras economic zone, Nakhchivan natural economic zone, which consist of 10 natural-economic regions: Absheron economic region, Guba-khachmaz economic region, SHAKI-Zaqatala economic region, a mountainous Shirvan, Ganja-Gazakh Lachin economic region-Lachin economic region, the Upper Garabag, Aran economic region, Lankaran-Astara economic region, Nakhichevan.Within Azerbaijan is the SouthEastern part of the Greater Caucasus. From the top of g. TeenRosso-to the top g. Babadag stretches the main Caucasian Ridge, East of Babadaga goes downgrading Ridge to the Caspian Sea. The highest peaks of the Caucasus Mountains in Azerbaijan are g. Bazaar-borrowed by Bazarduzi mountain (4489 m), g. Tfan (4197 m) covered with eternal snows. In the southwest of the main Caucasian Ridge breaks off to Ganykh-Agrichajskoj Valley where the rivers converge, carrying water from the ridge to the South of the Valley foothills are located. In the South-East of the large Caucasus is Absheron peninsula and adjacent foothills of Gobustan. To the North of the main Caucasian Ridge stretches the lateral Ridge, within Azerbaijan its eastern part. High peaks of g. Shahdag $(4251 \mathrm{ft})$ are covered with glaciers [1,2].

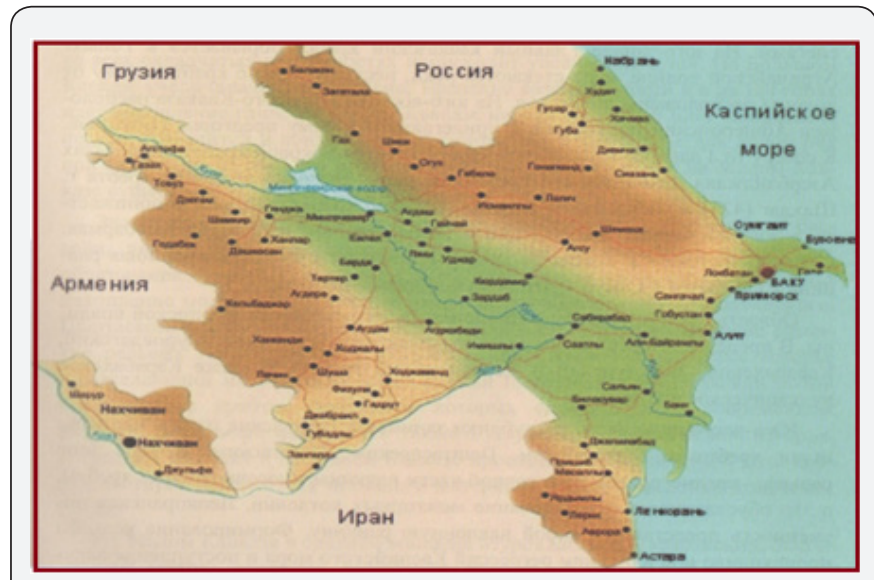

Figure 2: Map of Azerbaijan.
Lateral Ridge gradually descends in a south-easterly direction and ends at the apex of Beshbarmak. From the northeast to the Lateral Ridge abuts the sloping sloping plain and merges with the Samur-Devichinskoj lowland. The Lesser Caucasus area located southwest of the Kur basin. Within Azerbaijan here stand out the Shakhdag, Murovdagskij, Zangezur, Nakhchivan and Daralagezskij ridges, as well as Garabahskoe volcanic mountain. The South-Eastern part of the country occupied by Talysh mountains with longitudinal ridges: Burovar, Peshtasarskij, Talysh. In this zone, but Midland terrain mountainous part of numerous ridges, and this causes the formation of intermontane hollows. Lenkoran lowland is a sloping plain. Formation of the relief happened under the influence of the regressions of the Caspian Sea and the accumulative revenue of material from the mountains. Unlike major and minor Caucasus, this area has not been frozen chetvertichnomu. On the territory of the Nakhichevan Autonomous Republic are Zangezur and Daralagezskij ridges. Along the crest of the Zangezur mountain range forms the border between Armenia and Nakhchivan Autonomous Republic. Climatic conditions in Azerbaijan are complex and peculiar. More than half of the territory of Azerbaijan (58\%) covered by mountains, the remainder (42.8\%)-Plains and lowlands of the Azerbaijani territory with high mountains, Intermountain Hollows, valleys, volcanic Highlands formed over geological periods. The relatively small area the Republic has a whole range of deposits $[3,4]$.

Features of geological structure and available material on tectonics the entire territory of the Republic gives the opportunity to restore history to its relief from earlier geological eras. On the big and small Caucasus geological history traces the development of the relief from the upper Jurassic, Talyshe-since the beginning of the Paleogene in Nakhchivan Autonomous Republic-with the Paleozoic. A research Antonova, B.a. Budagov [5] at the beginning of the Oligocene early Miocene tectonic processes and as a result all folded surfaces increase the sushi. In the Greater Caucasus is increasing, raising Tfanskie Kusarskie and their deflection is the accumulation of clay. On small Caucasus along with clays is the accumulation of sand, gravelitov and conglomerates, sediment characteristic of river valleys when leaving the mountains. It is said that already at that time on small Caucasus existed river network. A significant part of the Kur basin was a saltwater pool, inside of which were located on the island. In the formation of Oligocene sushi in Talyshe, the central part of the falls, is the accumulation of a powerful, layers of Maikop retinue, Yardimli, education Peshtasarskogo, Burovarskogo ridges. In the middle and late Miocene development relief Azerbaijan intensifies. Central Vandamskoe lifting and separating their ZakataloKovdagskij perp has already represented the middle ranges, fragments of which are preserved in the modern relief. In the relief of Kusarskoe, also Beshbarmakskoe breached the uplift. On average, Miocene and small Caucasus change occurred. This is evidenced by the presence of sandy material layer of pebbles of conglomerates. On small Caucasus Murovdagskij, Miocene 
average Garabakh, Zangezur ridges obviously exceed the height of the Midlands and the Shakhdag and Daralagezskij Ridges do not reach the Midlands.

According to B.a. Budagov, g.a. Khalilov in the early late Miocene in the Greater Caucasus expands transgression of the sea. In the early Pliocene formation of mountain constructions of major and minor Caucasus, Talysh continues. In relation to the tectonic Tfansko Dibrarskaja-raising land is exempt from the sea. On the big Caucasus there was already a terrain that stretches to the town of Babadag. Marine pool occupied southeastern Shirvan. In the formation of the relief of the Lesser Caucasus, Nakhichevan AR, Talish in the early Pliocene major changes occurred. Tectonic processes during this period are expressed in raising major mountain ranges and the revitalization of the volcanism of the Karabakh Highlands. From this period also involves the formation of the South the Caspian basin and the formation of the Lankaran lowland [6]. Late Pliocene-beginning of a new era that is associated with the transgressiej sea, oceanic water erupt in the Caspian basin and form extensive bays. During the Pleistocene period a sharp climate change and this entails strengthening the tectonic processes of growth of the height of the mountain facilities, increased sedimentation, terrgenous material and the alternation of transgressions and regressions of the sea. In the Experimental zone formed band proljuvialnodeljuvialnoj plain. In the lower reaches of the rivers Bolgarchaja, Viljashchaja and other rivers formed cones. Mountain building of the greater and Lesser Caucasus continued to be formed and purchased the modern shape of the Caucasus Highlands in this period reached a height of $4000 \mathrm{~m}$. In the field of Garabahskogo Highlands volcanic activity was evident. The lava formed either step or plateau flows down the valleys of Tartar, Bazarchaja, Arpachay. In mountainous parts of the greater and Lesser Caucasus developed mining and Valley glaciers. On the territory of the greater and Lesser Caucasus folded Jurassic and chalk slates meet Sandy limestones, sandstones, limestones, collected into complex folds. In the South-Eastern Caucasus developed deposits of chalk, represented by clays, limestones. On the territory of the Nakhichevan AR Miocene deposits denominated solenosnoj thickness. According to M Kashkaja [7] srednedevonskie sediments are represented by coral limestones, sandstones, and Shales. Verhnedevonskie sediment is sand, argillaceous schists, quartzites. The power of these deposits amounts to $1100 \mathrm{~m}$. Perm deposits consist of Marly limestones with a capacity of several tens of meters. On the territory of the greater and Lesser Caucasus meet Jurassic deposits. This argillites, sandstones are found in high jure vulkanogennye rocks in the upper jure-carbonate. Lowland territories of Azerbaijan are folded by alluvial, alluvial debris and marine Quaternary sediments $[8,9]$.

\section{Climate}

Azerbaijan, as a mountainous country, at the same time has extensive lowlands, valleys and in connection with a variety of surface topography has a varied climate. From the invasion of cold air masses from the North of the Republic protects the main Caucasian Ridge. Depending on the height above sea level, climatic conditions Azerbaijan vary. With the show in the mountains the average temperature falls. Of the 11 installed on globe main climate types $[10,11] 8$ types found on the territory of the Republic, namely

Climate Semi-Desert and Dry Steppe: It is endemic to the territory of the Kur depression, Ganja-Gazakh array and the Priaraksinskoj lowlands area of Nakhchivan. This region is characterized by hot summers, mild winter with little rainfall from intense evaporation. The air temperature ranges from +12 to -150 . Months of July and August is hottest months, Januarythe coldest month. Rainfall ranges from $430 \mathrm{~mm}-185$, relative air humidity from $50-60 \%$ in summer, $75-80 \%$-during the winter months. Northern winds are found on the Absheron peninsula in all seasons, sometimes reach hurricane force (Baku Nord or "Khazri"). These winds blow in the summer of 2-3 days.

Warm-Temperate Climate with Dry Winters: Characteristic of mountain zones of southern slope of Great Caucasus (1400-2000 m), alazan-Avtoranskoj Valley (200-500 $\mathrm{m}$ ) and the eastern slope of the Lesser Caucasus (1400-1500 m), this region is temperate moist, mild winters and moderately hot summers. Such a climate favourable for cultivation of cereals, grapes, also to the spa zone (Roads, Sheki, zagatala, Ajikend).

Warm-Temperate Climate with Dry Summers: Inherent in the Experimental area. Mild, wet winters and moderately hot, dry summers and rainy autumn. Rainfall reaches $1300 \mathrm{~mm}$ per year. This climate is called wet-subtropical, is favorable for cultivation of citrus fruits, tea and fruit-melons.

Cold Climate with Dry Winter: Typical Alpine and mountain area of the Lesser Caucasus and (1500-2700 m) and Northeastern slopes of the Greater Caucasus (1000-2700 m). This region due to the cool summer, a harsh winter, a large number of solar radiation and the presence of mineral springs suitable for sanatoriums and holiday homes (Lake GekGel, Istisu).

Cold Climate with Dry Summers: Inherent to the mountain zone of Nakhchivan. Compared with the Priaraksinskoj stripe there is more moisturizing, less hot summers, more cold and snowy winter.

Warm-Temperate Climate with Uniform Precipitation: Noted in the forest zone of southern region $(600-1500 \mathrm{~m})$ and North-eastern slopes of the Greater Caucasus (200-500 m). Mild winters and moderately hot summers.

A Cold Climate with Abundant Rainfall: Found in the Alpine zone of the greater and Lesser Caucasus.

Vegetation: Vegetation of Azerbaijan is very varied. On the territory of the Republic has around 4100 vegetation types. Vegetation is distributed on tall steps depending on zonal changes in climate and soil, i.e. According to the law of vertical 
and horizontal zonation. Throughout the history of the flora was subjected to changes, i.e. Since the Cretaceous era to the present day due to changes in physical and geographical conditions, vegetation of Azerbaijan had changed. Historical Geology data show that at the end of the Cretaceous and early tertiary epoch of the Caucasus was an island with a humid climate. The area was covered with lush evergreen vegetation, but this ancient vegetation has not survived to the present day and in the tertiary period was expelled. Glacial period introduced new changes to vegetation. With the retreat of the glaciers, forest vegetation occupied the mountain slopes. This vegetation, a few vidoizmenivshis, has been preserved to our time. In the modern vegetation of Azerbaijan you can highlight certain types of landscapes and vegetation.

For example, the Kur depression, Absheron, South Mughan, Samur-Devechi lowland, Priaraksinskoj plain and Foothill semideserts. Within Azerbaijan at an altitude 1500-2000 m above sea level vegetation is represented by broadleaved forests. They include: Georgian oak, hornbeam, Linden, maple, in the lower parts of the belt include chestnut, Caucasian persimmon. srednegornogo forests belt: predominate East beech, hornbeam, maple, ash, Linden. In the western slopes of the bushes "Rhododendron luteum», on East Juniper "juniperus» Climbing even higher. characteristic of the zone of East oak forest (Quercus macranthera) forms the Park oak. Subalpine vegetation is divided into 2 zones: lower, upper. The lower notes, from 1600 to $2000 \mathrm{~m}$ above sea level. This includes forest edges, clearings. Dominated by subalpine, poslelesnye, tall, plains and meadows. Upper zone within heights from 2000-2700 m above sea level. It is dominated by the motley ostepnennye meadows and steppes. Above 2600-3200 m Nival belt with cold climates are almost devoid of vegetation.

Lankaran-Astara region depending on the humid-subtropical climate vegetation has a specific species composition. A study of the flora of this area was A.a. Grossgejmom [6], and Li Prilipko [8]. The main breed of Lenkoran lowland forest area is DemirAgach (Porrotia persica), hornbeam (Carpinus caucasica). As Bush advocated shrubs of Hawthorn (Crataegus sp.), Ruscus (Ruscus hyrcanus), medlar (Mespilus germanica). In lowland forests at the edges and glades grow vines, silk Acacia (Albizzia julibrissi) Vegetation of Nakhchivan also formed depending on the climate. According to Li Prilipko all with Arax lowlands and foothills takes wormwood semi-desert. Rising above the predominant vegetation of lugovostepnogo nature. In the area of the Highlands on the slopes of vegetation does not form a closed cover. Intervals between shrubs and trees are occupied by the lush, lush meadows, dry meadows, depending on the steepness of slopes and soil cover. Vegetation is one of the main factors of the soil-process. Decaying plants accumulate a large amount of soil organic matter. Depending on soil organic matter enrichment S.a. Zakharov allocates 3 type of vegetation: wood, Cliff, travjanistuju. Wood i.e. forest vegetation occupies a large area and rises to a height of $2700 \mathrm{~m}$ above sea level. $\mathrm{m}$ on the southern slope of the main Caucasian Ridge and alazanAvtoranskoj Valley forests occupy almost $34 \%$ of the area. In the north-eastern slope and $13.8 \%$ of the Caspian depression. The Absheron peninsula, Gobustan belong to treeless areas. In GubaKhachmaz zone large space occupied by forests of oak, poplar, hornbeam, Elm, mulberry. Compared with forest shrub takes a smaller area. Woody shrubs such as: Hawthorn, dogwood, medlar, a dogrose, a sloe found on the edges of forests. Other shrubs, rhododendron derzhitree, Astragalus, Juniper took steppe and semi-desert area. By type of grassy vegetation S.a. Zakharov distinguishes semi-desert, desert, steppe, meadow, Sandy, Rocky, swampy. Steppe vegetation covers Shemakha Highlands, meets on Guba-Gusar plain. Among the mountainsteppe vegetation representatives of legumes, with the deep root system, form the high grass. Among the most common encounters, sweet clover, sainfoin clover, vetch, chick peas.

The Soil Cover: Formation of the relief, climate and human activities affect the appearance of the soils of Azerbaijan. The soil is represented by all major soil types and obeys the law of horizontal and vertical zonation. Among the factors of soil formation plays an important role in relief, because the vertical soil zones are in direct dependence on the vertical zonation, climate and vegetation. In the mountainous part of Azerbaijan nature of the terrain is very difficult and this is the reason of runoff of surface waters. On the supervision of G.A. Aliyev [1] very often with mountainous part-sloping plain carried products of weathering. In the mountainous part of the greater and Lesser Caucasus common mountain-meadow soil, where the soil-forming process takes place under the influence of grassy vegetation. These soils are well expressed in the humus horizon. Alpine region occupied by sub-alpine and alpine meadows, is a rich pastures.

a. Brown mountain-forest land occupied zone of Northern and North-eastern slopes of the Lesser Caucasus, the southern and northern slopes of the main Caucasian Ridge formed under the beech and hornbeam-beech forests.

b. Brown mountain-forest land are located under the cover of dry forest with dense grass stand. 3-4\% content of humus, humic acids predominate over fulvoacids-alkaline reaction.

c. Soil dry steppes - gray-Brown Earth soils desert steppes. occupy a strip of the foothills and low mountains with moderately warm and moist climate, where poluvlazhnym dominates steppe vegetation. Gray-Brown Earth well humidified flowing from the slopes atmospheric precipitation. Named soils developed in deluvial rocks and forests, they have good moisture-holding capacity and provide vegetation moisture. Grey-brown soil of Nakhichevan AR compared to other areas of Azerbaijan contain less humus.

d. Gray- in strechajutsja on the Kur depression, Nakhichevan AR on the flat part in terms of climate semi- 
arid. Depending on soil conditions, the nature of the species, salinity, they are divided into subtypes. Since the climate in the grey zone of soil is characterized by hot and dry continental climate vegetation of this zone is poor and does not form a continuous turfing. Accumulation of humus is negligible. Saline and alkaline soils develop in terms of climate semi-arid. These soils contain in their profile highly soluble salts in toxic for crops. The formation of saline soils is associated with the accumulation of salts in groundwater and rocks and the conditions conducive to their accumulation in soils. Common in Mil, Shirvan, Salyan Plains.

e. Soils of floodplain-develops on river valleys. Is alluvial and alluvial-forest soils have been formed with the participation of the they fluvial. Alluvial provide natural fertilizer than plodorodnee napilok is, the more it develops natural vegetation in the floodplain.

f. Soil moist subtropical climate- common in Lankaran region, mainly zhovtozemah, poor in humus with sour reaction, slightly podzolized are polyvalent metals $(\mathrm{Fe}, \mathrm{Al})$. In a small number of Experimental zones there are also red soils. It has been established that these soils have developed on the red-colored crust of weathering on damp subtropics with a predominance of podzolic process, characteristic in acidic Wednesday. But on the other hand signs podzolization manifested not clear-cut, since decomposition of organic substance formed a large number of bases and neutralizes the acidic reaction.

\section{Hydrography}

The hydrographic network of the Azerbaijan formed over a long period and of tectonic processes experienced various changes. Under human activities and natural processes it and now continues to change.

In the Republic of nachityvaetsja 1000-1200 rivers in General, most of them long, or more than $100 \mathrm{~km}-21$, from 5 to $100 \mathrm{~km}-67$ rivers, length of $5 \mathrm{~km}$ and less-850 rivers.

All the rivers in the Republic belong to the basin of the Caspian Sea. They can be divided into three groups:

1) The rivers of the Kura basin,

2) The rivers of the Araksa basin

3) Rivers directly flowing into the Caspian.

River network is distributed unevenly in the territory of the Republic. In the mountains the hydrographic network strongly developed, depending on the terrain and abundance of precipitation. The greatest development of the hydrographic network reaches at altitudes of 1000-2500 m, srednegornom zone.

The largest water artery of Azerbaijan-Kura, within the Republic of its length is $900 \mathrm{~km}$. It originates in Turkey, the length of the river is $1072 \mathrm{~km}$. Between the main Caucasian Ridge and Lesser Caucasus is the Kura-Aras lowland, which carry their waters Kura and Arax.

According to the method of feeding the River are divided into

1) snow-soil.

2) rain-soil

3) soil-rain.

4) soil-snow.

The first type consists of r. Kura River with highly located watershed. They belong to the North-East and the southern slope of the main Caucasian Ridge. This Samur, Gusarchay, r. and Turyan tributaries of the river Gumchai, Damiraparanchay. On these rivers rain feeding. The second type are the low-lying River watershed. Such rivers are found in the major and minor Caucasus and Lankaran region. This is Divichichay, Ahchaj, Shabranchaj, Kuruçay, flowing with Lateral ridges NorthEast slope of the Great Caucasus and also the river current to Kobustanu. Tugchaj, Atachai Rivers Traverse. Tea. Here snow food is $5 \%$. In the small Caucasus among rivers, with rain-soil nutrition include the rivers: Tauzchaj, Ahyndzhchaj, Dzhagirchaj, Qarqar River, Kendelenchaj, Kuruçay. A third type of food-soil-rain fall River, flowing from the South and the north eastern slopes of the main Caucasian Ridge, it is Dashagylchaj, Aldzhiganchaj, Turyan, Goychay, Velvelichay, Karachay. These River obvodnjajutsja at the expense of emerging on the surface of the groundwater. Here snow eating-not more than $20 \%$. Republic of Lakes is poor. Largest of them is Lake Adzhikabul, sarysu, Akgel. The most beautiful-gek-gel and Maralgel. The Caspian Sea is the largest lake in the world. It was formed in the second half of the anthropogenic period for its huge dimensions and for the name of the sea salinity [12-15].

\section{Problems of Irrigated Agriculture in the Context of Azerbaijan}

It should be noted that due to the complexity of the physicalgeographical conditions and anthropogenic influence, $41.8 \%$ of the land is exposed, to varying degrees, erosive processes. Currently land in Kura-Arax River lowland zone of strongly saline. The total number of saline land in the Republic is about 600 thousand hectares, although some of them are equipped with a collector-drainage network. For their washing and recovery requires additional quantity of fresh water. In Azerbaijan, traditionally cultivated water-intensive crops. And water consumption on 1 ha of irrigated land is lagging due to water shortage, leaving instead of 6-7 irrigation-watering 2 plants receive [2] As you know, on climatic conditions Azerbaijan differs from all other regions of 11 climatic zones existing in nature, 9 takes place in our Republic. This fact requires a special approach to solving problems of agricultural production. The situation was compounded by the fact that the rainfall in the territory of the Republic is very uneven, and in some regions is insufficient 
to meet the needs of selshozkultur during their growing season, i.e. water shortage nalichen. Water resources of Azerbaijan make up 32.3 billion. $\mathrm{m}^{3}$ per year, and in dry years, that figure drops to 23.16 billion. $\mathrm{m}^{3}$ (95\% probability). Of these water volume at a fraction of their own water resources accounting for 10 billion. $\mathrm{m}^{3}$. as a result, the Republic has only $14 \%$ of the total water resources of the Caucasus [3]. Prior to the 1990 year Azerbaijan was one of the largest agricultural producers and exporters of raw cotton, tobacco, grapes, wine and vodka products, fruits and vegetables and canned products. However, after the transition to a market economy, there has been a change in the structure of sown areas.

Table 1: Exposure to soil erosion in mountain areas of Azerbaijan.

\begin{tabular}{|c|c|c|c|c|c|}
\hline \multirow[b]{2}{*}{ Areas } & \multirow[b]{2}{*}{$\begin{array}{c}\text { Total } \\
\text { area HA }\end{array}$} & \multicolumn{4}{|c|}{ Including Exposure to Erosion } \\
\hline & & $\begin{array}{c}\text { Not } \\
\text { Podverzh. } \\
\text { HA \% }\end{array}$ & Little & Medium & Strongly \\
\hline \multirow{2}{*}{ Dashkesan } & \multirow{2}{*}{90.3} & 23.3 & 18.3 & 25.6 & 23.1 \\
\hline & & 25.8 & 20.3 & 28.3 & 25.6 \\
\hline \multirow{2}{*}{ Gədəbəy } & \multirow{2}{*}{150.3} & 73.6 & 20.1 & 29.8 & 26.8 \\
\hline & & 49 & 13.4 & 29.8 & 27.8 \\
\hline \multirow{2}{*}{ Kelbedzher } & \multirow{2}{*}{124.3} & 48.4 & 27.2 & 18.9 & 29.8 \\
\hline & & 38.9 & 21.9 & 15.2 & 24 \\
\hline \multirow{2}{*}{ Lachin } & \multirow{2}{*}{166.5} & 56.7 & 26.3 & 36.7 & 46.8 \\
\hline & & 34.1 & 15.8 & 22 & 28.1 \\
\hline \multirow{2}{*}{ Kubadly } & \multirow{2}{*}{79.8} & 25.7 & 6.9 & 28.7 & 17.5 \\
\hline & & 33.5 & 8.6 & 36 & 21.9 \\
\hline \multirow{2}{*}{ Zangilan } & \multirow{2}{*}{72.5} & 24.6 & 16.4 & 14.6 & 16.9 \\
\hline & & 33.9 & 22.6 & 20.2 & 23.3 \\
\hline \multirow{2}{*}{ Lerik } & \multirow{2}{*}{136.5} & 43.6 & 19.4 & 27.8 & 44.7 \\
\hline & & 32.2 & 14.3 & 20.5 & 33 \\
\hline \multirow{2}{*}{ Yardimli } & \multirow{2}{*}{12.5} & 25.1 & 12.6 & 10.6 & 24.2 \\
\hline & & 34.6 & 17.4 & 14.6 & 34.4 \\
\hline \multirow{2}{*}{$\begin{array}{l}\text { Mountainous } \\
\text { part } \\
\text { Goranboja }\end{array}$} & \multirow{2}{*}{$\begin{array}{l}57.6 \\
20.8 \\
19.5\end{array}$} & \multirow{2}{*}{$\begin{array}{c}7.7 \\
36.1\end{array}$} & \multirow[b]{2}{*}{33.9} & \multirow[b]{2}{*}{13.4} & \multirow{2}{*}{$\begin{array}{c}9.6 \\
16.6\end{array}$} \\
\hline & & & & & \\
\hline \multirow{2}{*}{ Julfa } & \multirow{2}{*}{99.4} & 9.9 & 16.3 & 25.3 & 47.9 \\
\hline & & 10 & 16.4 & 25.3 & 48.1 \\
\hline \multirow{2}{*}{ Shahbuz } & \multirow{2}{*}{81.4} & 61.1 & 5.4 & 15.7 & 14.2 \\
\hline & & 19.8 & 6.6 & 19.3 & 54.3 \\
\hline \multirow{2}{*}{ Ordubad } & \multirow{2}{*}{92.4} & 7 & 9.5 & 13.5 & 62.1 \\
\hline & & 7.6 & 10.6 & 14.6 & 67.2 \\
\hline \multirow{2}{*}{ Absheron } & 535 & 57.5 & 116.8 & 165.5 & 195.5 \\
\hline & & 10.7 & 21.8 & 30.9 & 36.6 \\
\hline
\end{tabular}

Currently, crops occupy 1 million. 50 thousand. HA-with a total yield of 2.8 million. tons, mainly wheat. Cotton acreage has been reduced in the Republic that is subject to the conditions of the market. The Republic belongs to the land-poor countries as per capita here is necessary no more than 0.2 ha of arable land. In Azerbaijan, in addition to soil erosion, there are problems associated with desertification (Table 1). They are accompanied by the restructuring of the thermal balance of the region. It is known that the desert is an arid territory, almost devoid of vegetation and soils with low biological productivity. Therefore, the study of desertification and development of measures for their implementation may suspend the processes of desertification facing the Republic. On water issues required to conduct scientific research on mountain slopes with irrigation technology mikrodozhdevaniem, with macro-and microelements, as well as rational use of soil and water in lowland and Foothill areas and sloping lands of the Republic of Azerbaijan. On this matter the following cash:

a) development and introduction of water saving, environmentally sound irrigation technique and technology;

b) development and implementation of highly effective means for draining the irrigation systems;

c) development of recycling of waste and drainage water;

d) developing measures for salinization;

e) development of events and studies on prevention of land degradation;

f) the development of activities to combat desertification.

It should also be noted that one particularly important development direction of Agriculture of Azerbaijan is the crop of particular importance to ensure that the needs of the population in Azerbaijan have food-grains and legumes. So each year the above crops are grown in different soil and climatic conditions of the Republic, which required a spectacular selection strategy for a particular agro-ecological region. The successful solution of these tasks depends on the creation of a widely adapted, disease-resistant, high-yielding and stable genotypes of cereals and legumes that depends primarily on the enrichment of the world's gene pool.

\section{The Problem of Salinization in Azerbaijan}

In past years at 593 thousand square. HA of irrigated land (41\%) were conducted comprehensive reclamation activities. As a result of large-scale land drained area expanded and currently represent 593 thousand. HA, which at 310.4 thous. hectares there is an open network of horizontal drainage. In 264, 4th. HA-closed drainage and 13.2 thousand hectares. -vertical drainage. The length of the collector-drainage network is characterized by the following data: closed drainage-10 thous. $\mathrm{km}$, open drainage-9.7 thousand. miles, a collector of different order-11.6 thousand. km. Meanwhile, 43.8 per cent of irrigated land, i.e. $633.8 \mathrm{HA}$-saline, to varying degrees, including 429.8 thousand hectares (68\%) the Earth is slightly saline, 139.8 thousand ha (22\%)-medium saline, 66.2 hectares $(0.4 \%)$ are strongly saline. Salinization adversely affects the productivity of agricultural crops cultivated on the productivity of these lands. crops on average reduced by $23.0 \%$ in low salinization, $47.0 \%$ 
on average, salinization and $85.0 \%$-if a strong salinization. So for the desalination of these lands, as a rule, on a silnonozasolennyh stations and salt marshes, and flushing the capital is carried out in the lands with low and average salinity-agricultural activities rassolitelnye and agromeliorativnymi methods. Among these techniques prominently flush irrigation regime, including the use of charge (winter and spring araty) and current washing mezhvegetacionnye periods. The Azerbaijani Republic diverse soil and climatic conditions and there are nine out of eleven climatic zones existing on Earth. By the nature of same reclamation measures clearly identifies three categories of effective lands:

a. The soil is alluvial origin with chloride-sodium salt composition (Nal prevails in salinization) and high filtration capacity fast enough when the Office thus leaching of salts, agrofizicheskie properties of soils under leaching is not deteriorating:

b. Soil salinity chloride with chlorine-40-60\% from the tight balance, having toxicity threshold of $0.2 \%$. This soil is common in Salyan Plains and North Mughan;

c. Soil salinity sulfate-chloride type with chlorine-25-35\% dense balance having toxicity threshold of $0.3 \%$. This soil is common in Northern Southeast mughan, shirvani, a narrow strip of Agjabedi shirvani, Priaraksinskoj Valley, in the mil plain and in a narrow coastal strip along the Caspian Sea.

The soil is alluvial plains Foothill-proljuvialnogo origin with sulfate-magnesium-sodium composition and difficult soleotdachej, possessing in an unfavourable agrofizicheskimi properties susceptible to osoloncevanie in the process of washing:

a. Soil with chloride-sulphate salt composition containing chlorine-10-20\% dense remnant whose toxicity threshold of $0.4 \%$. This soil is widespread in shirvan plain, South of Mugan, is common in Holding the plain and partly in the mil plain.

b. Soil salinity, sulfate containing chlorine- $0.10 \%$ of the tight balance, having toxicity threshold of $0.4 \%$. Spread the soil developed shirvan plain, South of Mugan in Karabakh plain and partly in the mil plain.

c. Soil salinity sulfate-chloride type with a high content of gypsum (a0 4 2-3\%) containing chlorine-0-10\% from the tight balance, having toxicity threshold of $1.0 \%$. this soil is common in shirvan plain and South Mughan.

The soil is alluvial-proljuvialnogo or alluvial origin with some soda salts salinity with alkaline renakciju Wednesday:

a. Soil with sodovo-sulphate salinity, possessing a natural alkalinity, prone to additional osoloncevaniju when flushing, it contains soda in small amounts, the reaction Wednesday it is alkaline. Distribution of the soil occurred in individual farms-Mil and Karabakh Plains. b. Soil with sulfate-soda salinity, strongly-soloncevataja merged, the reaction of the soil solution is alkaline, the

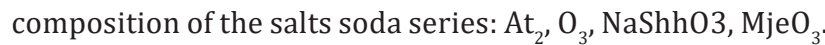
the soil is strongly dispergirovana, swells with moisture, water and soleotdacha is extremely low. This soil is spread on the cone stem r. Tartar, Krabahskoj steppe. In the Organization and conduct of the current flushing, flushing rules, assignment of depth predpromyvnoj processing, time washing the soil must be guided by the groups of soil and flushing to carry out differentiated by these groups. As a result of numerous studies conducted at pilot sites, "the Institute of Melioration, come up with specific recommendations for improving saline land in relationship to a specified category. On lands with high filtration capacity and chloride-sodium type of salinization of recommended ispolzanie "taktno-Strip and intermittent flushing". Essence taktno-Strip rinsing is the separation of the width of the aisle 3-5 parts. The strips are separated earthworks height $0.6 \mathrm{~m}-1.0$. soil flushing is carried out in stages. In the first phase the Central stripe is washed, the second central and adjoining thereto-Middle stripe, and the third is included and the baseband pridrannye. The essence of intermittent flushing is repeated pouring leaching cheques intermittently mezhduzalivkami for the time necessary to lower the groundwater in the central part of the mezhdrenja to a depth of $1.0 \mathrm{~m}$ from the ground -1.5 , and avoiding closure leaching and groundwater. With the implementation of the technologies of soil desalination homogeneously across the width of the mezhdrenja (thanks to the uniform distribution of industrial standards) and excludes overhead rinsate. Heavy impermeable land recommended capital flushing differentially, depending on lithological structure, degree of salinity and filtration properties of the soil:

a. The lands with a filtration coefficient $-0.300 .10 \mathrm{~m} /$ day . and if necessary rinse up to standards largest 10 thousand $\mathrm{m} 3$ /ha capital carried out washing in the usual way, against the backdrop of continuous deep drainage.

b. The lands with a filtration coefficient $-0.300 .10 \mathrm{~m} /$ day. and with the necessary rinsing 10-30 standards largest thous. $\mathrm{m} 3 / \mathrm{ha}$, the permanent deep drainage is enhanced by additional temporary drains during major cleaning.

c. On the lands with low water permeability, coefficient of filtration $-0.100 .05 \mathrm{~m} /$ day. and when the power of compacted upper layer does not exceed $0.6 \mathrm{~m}$. -0.7 and leaching norm required less than 10 thousand. m3/HA, the capital is being held against the backdrop of continuous washing deep drainage with deep processing of soil before the vote.

d. On the lands with the same coefficient of filtration and the same power of compacted upper layer, as in the previous case, but with the largest 10-30 leaching norms requiring th. m3/HA capital held against the backdrop of continuous 
washing deep and temporary minor drainage in combination with the application deep soil before washing.

e. On the lands with a filtration coefficient $-0.10 \quad 0.05$ $\mathrm{m} /$ day. and the presence of compacted upper thickness exceeding $0.6 \mathrm{~m}-0.7$ regardless of the degree of the original soil salinization capital flushing takes place against a backdrop of deep drainage from the permanent and temporary, when coupled with the application deep soil before flushing.

f. On the lands with yacht and Bared soils with a filtration coefficient $0.05 \mathrm{~m} /$ day. When the power of the upper horizons of the merged over compacted $0.06-0.7 \mathrm{~m}$. capital flushing takes place against the backdrop of deep and small drainage permanent temporary when they are combined with a deep soil before washing and using himmeliorantov or jelektromelioracii.

In sodovo-saline soils, the main criterion for reclamation is the degree of alkalinity tolerance for and content of sodium salts (normal and bicarbonate). Land subject to chemical amelioration and leaching on background of drainage. of chemical acidic had proved to be effective and ameliorators physiological salt, acid or neutral salt two and trivalent metals. Almost syromolotyj gypsum (aSO4h2P2o) is a widely-used drug. The above reclamation techniques (taktno-Strip flushing, flushing amid temporary small drains and deep tillage, gypsum on), with the exception of jelektromelioracii and chemical chalking, were widely used in reclamation practices in bringing the irrigated area increased from year to year. These techniques were industrialized and successfully implemented with the former Soviet Union. In terms of private property, their application difficult and approaches for desalination of saline and prone to salinization of lands are folded differently. In connection with land reform from the General Fund of the Republic in 8641.5 thousand. g. 3.8 million hectares remain in State ownership, 2.74 million. HA is allocated to municipalities, and 2.1 million. HA dealt private landholders, i.e. farmers, cooperatives, associations, etc. in State and municipal lands conducting reclamation measures on land distribution now due to logistical insecurity is virtually suspended and resume the above washing technology will continue to be implemented. The land allocated to private landholders, typically, are slightly saline and medium saline and medium saline soils, and individual stains strongly and very strongly saline lands. On these lands, mainly needed is implementation of leaching regime of irrigation vlagozarjadochnyh, and current leaching, which drafted individual recommendations and instructions. The most appropriate of these lands are the crops of rice. In addition, the technology of horizontal washing deep furrows, which under the force introduce a private trader in their economy. In terms of concentration of major stocks of salts in the upper horizons ( $-0.600 .4 \mathrm{~cm}$ ), as well as in freshwater and brackish groundwater, it is advisable to use a horizontal washing against the backdrop of deep furrows.
Flushing should be done in the following sequence:

a. rinsing water flooded furrows-one that is supply, others as obtochnymi, serve as drainage;

b. flooded and mezhborozdnoe space;

c. flooding of mezhborozdnogo space continues, flooded obtochnye furrows, close plays the role of drainage;

d. rinsing continues with flooding the entire area, including the river bed deep furrows.

The advantage of horizontal flushing is that rarely washing process is accelerated drainage of salt is produced, bypassing the underlying horizons.

\section{Soil Erosion Problems in Azerbaijan}

Study of soil erosion in Azerbaijan has great importance because it is mainly a mountainous country and in its territory are developing all kinds of erosion processes. Development of erosion processes on the territory of Azerbaijan takes the form of flushing, erosion, gully formation, landslides, salt flows, as well as of the formation of depressions and other forms of blowing. There is also a role of improper human activities when using mountain meadows, steppes and semi-deserts, outstanding runoff precipitation, as well as the soil without taking into account run-off and wind direction [4]. In different physiographic regions and districts of Azerbaijan, depending on the intensity of use of the territory, erosion processes proceed differently. Accelerated erosion in strong form manifests itself in mountainous and partly to the mountain zone, wind erosion-Foothill and partial lowland areas. The main factors causing soil erosion development in Azerbaijan are: mountain-meadow-grazing unsettled area, concentration of its performance excluding pasture (livestock), unsettled run on watering, etc.; in a mountain-wood zone is incorrect, indiscriminate felling of forests, grazing in the forest, improper skidding, stubbing the forest on steep slopes for crops, etc. On the territory of Azerbaijan is the most common surface water erosion, manifested in almost all areas of the Republic, a few less-gully, even less wind erosion, confined to certain areas. Climatic conditions are one of the natural factors that contribute to soil erosion. The greatest water erosion has during the spring in the Alpine region and water-course restriction in fallout torrents-summer period; wind erosion-in the spring and summer seasons. The presence of strongly dismembered terrain, complex geological structure, occurrence of different breeds, different resistance against destructiveness of water in mountain and Foothill areas, especially in the steep slopes under the agricultural culture, contributed to the accelerated erosion. On the territory of Azerbaijan absaljutnaja elevation varies from $29 \mathrm{~m}$ in the coastal lowland zone-up to 3000 $4000 \mathrm{~m}$ in the mountainous part of the Republic. Azerbaijan has territory, strongly raschalennye estimation-beam and long Internet occupying mountain and Foothill areas. The length of the network varies from 2 -up to $6 \mathrm{~km}$-at $1 \mathrm{~km} 2$, and sometimes 
more. The depth of local bases of erosion varies from a few meters to 1600 meters and more. In connection with strong rugged territory inclination range from 3-to 450 or more (steep and steep slopes) Vegetation, as Woody and herbaceous, soil and water conservation is of great importance. In the presence of dense vegetation cover accelerated soil erosion and flushing. Soil erosion studies in various parts of the Republic gave an opportunity to establish the development of erosion processes in individual areas and draw up a soil-erosion map of Azerbaijan. Plane wash soil are almost in all parts of the Republic, especially in the mountainous and Foothill areas. In the foothill zone has a broad development of gully erosion, and partly by the wind. Flush the soil on the Caucasus when steep slopes reaches for the year 50-300 t/ha. The growth rate of ravines in Azerbaijani territory in the mountainous area reaches 3-5 $\mathrm{m}$, while in the foothill zone-5-10 $\mathrm{m}$ for the year. The mountain zone is characterized by the development of data of ravines (Figure 3).

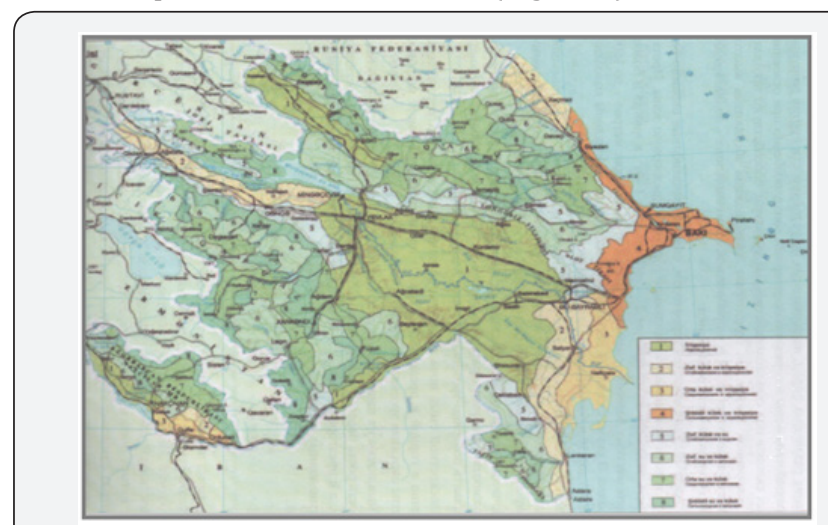

Figure 3: Soil erosion Map of Azerbaijan

\section{Agriculture in Azerbaijan}

Azerbaijan's geographic location makes it a strong solar radiation and heat, creates an opportunity for the cultivation of many crops. According to information on 01.01.2009. from 8.64 million ha of land area-4.75 million hectares suitable for agricultural purposes, while 1.8 million ha is occupied by farmland [10]. Irrigated area in Azerbaijan is 1.4 million hectares. Per capita in Azerbaijan falls 0.98 hectares of land and 0.21 ha of farmland. Internal and external policy in short lines provided the development of relations with foreign countries, and, since 1995, real and permanent growth of the country's economic potential. "The GDP in Azerbaijan in 2008, reached 38.0 billion. manat. The share of agriculture in GDP structure is 5.8\%.

\section{Agriculture and Its Role in the Economy of the Country}

Agriculture is the traditional production area economy in Azerbaijan. The territory was originally the basis for the development of farming and animal husbandry. Conducted archaeological excavations prove that the territory of modern Azerbaijan in 6-8 Millenia b.c. grown grain crops, developed viticulture, SilkWorm breeding and fruit growing. Most of the country was mountainous terrain, which is why livestock played a crucial role in the lives of people living in that territory. It was at that period the country started exporting to Europe and on the East by high-quality wines, carpets, leather and silk. Development of the oil industry in the early twentieth century in Azerbaijan has increased investment in the oil sector, including agriculture. There has been a rapid growth in the development of viticulture in the western part of Azerbaijan produced highquality wines. In addition, oil tycoons (H. Z. taghiyev, brothers Nobels, Rothschilds etc.) laid out major investments in the development of weaving that has contributed to the development of cotton, silk and wool production. Therefore, processing of agricultural products has played an important role in changing the structure of employment. After the great patriotic war, Azerbaijan's agriculture has entered a new milestone of its development in 70-80-ies of XX century reached its peak. At that time, $45 \%$ of GDP, $40 \%$ of employees and $33 \%$ of the fixed assets of the country accounted for the agro-industrial complex Since 1995 as a result of agrarian reform, land and property owned by collective farms and State farms were irrevocably divided among the rural population processing enterprises have been privatized. There are currently 869.3 million (3438.6 thousand persons) and small family farms, 826 thous. people got their privatization Pai. $48 \%$ of the population lives in rural areas. Agriculture occupies a very large share in employment levels among the sectors of the economy. Agriculture compared to other areas of the economy has a higher growth rate. For example, "GDP in agriculture in 2003 amounted to $5.6 \%$ in 2008 and $6.1 \%$. The growth of agricultural production refers to strengthening export capacity in the country.

\section{The Situation of Agriculture and Its Development}

The basis of agriculture in Azerbaijan consists of two large spheres-crop and animal production. Currently, the crop is given development priorities areas such as grain, cotton, vegetables, potatoes, fruit growing, viticulture, tobacco growing, livestock breeding development focus poultry farming and horse breeding. $63.1 \%$ of agricultural production in 2008 г. crop production, accounted for $36.9 \%$ for livestock. In 2008 compared with 1995, the share of crop production increased by. $4.5 \%$, and the proportion of livestock fell by $4.5 \%$. The total area of sown areas, including under perennial plants, reached in 2008 r. 1634.2 thousand hectares. statistical observations over the past ten years show vigorous growth in crop production the share of cereals, legumes and vegetables, potato and vegetable plants. In line with the year 2008, the share of grains and legumes (59.6\%), fodder plants $(23.2 \%)$, vegetables $(5.4 \%)$ and potatoes $(4.6 \%)$ was the highest in the structure of sown areas. This trend comes from the aspirations of farmers, primarily, to provide themselves with food. Along with advances in the production of agricultural products in comparison with 1995 g. agriculture is undergoing structural changes. If in 2008 compared with 1995 g. Reduced production of cotton, tea, tobacco and grapes, sugar beet production has been growing at 6.9 times, garden plantsin 9.7 times, potato-6.9 times. Compared to the 1995 year in 2008 year grain production increases by 2.7 times, vegetable 
production-2.9 times, fruit-in 2.2 times. During this period, along with the growth of quality indicators in crop production increase and quality indicators. Currently, the country pays special attention to growth performance in agriculture. For example, in 2008, 603.9. th. hectares or 40.3 total sown area were brought under cultivation of grain crops. Agrarian reforms had had a positive impact on the development of animal husbandry. In 2008 compared with 1995 g. Livestock has grown 1.5 times and reached 2549.5 thous. animals, including cows and bulls increased 1.6 times (1230.8 thousand), sheep and goats-1.8 times (8203.4 thousand), birds-1.7 times (22352 thousand). Along with the growth of livestock increased agricultural production and productivity of agricultural enterprises. In 2008 (compared with 1995 g.) meat production increased 2.1 times, milk-1.7 times, wool-1.6 times, eggs in 2.2 times. It should be noted that the attention paid by the Government of the Republic of agriculture led to the dynamic development of the the agroindustrial complex of the country, the rapidly changing socioeconomic image of Azerbaijani villages.

\section{The Strategy and Priorities of Agriculture in Azerbaijan}

Strategy for the agricultural sector, as indicated in the State program is to ensure food security. Priorities for crop production in agriculture is to develop crop, cotton-growing, fruit-growing and viticulture, vegetable crops, tobacco, seed production and breeding of seedlings. In the livestock sector priorities are breeding, kormovodstvo, processing of agricultural products, agro marketing joint, simbhaoli sugars. Important tasks of agriculture are poverty reduction and creation of new jobs. Along with the above tasks, it should be noted and tasks as providing information and advisory services in the agricultural field, strengthening of material and technical base of research enterprises, reorganization of their activities on the basis of the requirements of a market economy. One of the main directions of economic output in the country and improving the nutrition of the population at the expense of local producers.

As criteria of execution of the State program to 2015 g. are the following targets:

a) 900 thousand hectares of sown areas under grain crops, yield-32c/hectares, total harvest is 2.8 million tons

b) meat production-up to 340 thousand. tons of milk and dairy products-up to 2.4 million tons

c) industrial meat production birds -80 thous. tons, eggs1.3 billion. pieces

d) potato production-1.12 million. tons

e) production of vegetables and garden plants-1.72 million tons

f) manufacture of fruit-800 thousand. tons

g) -sown area of oil crops-135 thousand. tons h) -sugar beet sown area-20 thousand. tons

i) -manufacture of tea leaves-3 thousand. tons

j) -forage crops sown area-500 thousand hectares

k) -the annual production of high-quality balanced mixed fodder-2 million tons.

\section{State Support of Agriculture}

The following are activities undertaken by the State to the development of the agricultural sector through the rational use of the country's raw materials, natural and labor resources:

a) exemption from the tax burden of producers of agricultural products in accordance with the laws of November 28, 2003 and from November 25, 2008, signed by the President of the Republic of Azerbaijan

b) Manual 40 manats ( $\$ 50$ United States) issued to agricultural producers for each hectare of sown area and for the cultivation of perennial plants based on resolutions of the Cabinet of Ministers dated 15 February, 13 November, November 16, 2007, 13 June and September 22, 2008 in the framework of the implementation of the orders of the President of the Republic of Azerbaijan from January 23, 2007

c) Manual 50 manats (\$63 United States) issued to agricultural producers for each hectare of cultivated land and supplied by OAO "agroleasing", and other legal and physical persons of $50 \%$ discount on sold producers of agricultural fertilizers;

d) payment of $50 \%$ of the sum insured-for insurance fees on wheat, barley, maize, sunflowers, potatoes, sugar beets, vegetables, fruit, citrus and grapes

e) $50 \%$ discount on future public expense rajonizirovannye wheat seeds

f) $70 \%$ discount on fertilizers for each hectare of sown areas

g) $50 \%$ discount for implemented by tribal cattle purchased JSC "agroleasing", etc.

\section{Conclusions}

a) For the correct development of Agriculture of Azerbaijan should identify priority areas for natural resources. One of the priority directions in the Republic is soil and water conservation.

b) Animal production should increase the quality and quantity of forage. To produce high-quality forages must introduce new technologies of their preparation. The restoration and preservation of the gene pool of cattle.

c) Intensive use of soil in small farms for the cultivation of cereals and fodder. 
d) Activities towards the consolidation of small farms into cooperatives.

e) Organization of seed and grain legumes in farms, the selection of plants that are resistant to extreme conditions. Development and application of technology of mowing for high yields with the preservation of the ecological balance and restoration of soil fertility.

f) The development of measures to prevent soil degradation and salinization, waste and drainage water, the fight against desertification. Development and introduction of safe equipment and vodasberegajushhej irrigation technologies.

g) Measures to combat soil erosion on the territory of Azerbaijan should be of a comprehensive nature and consist of Agrotechnical, forest meliorative, hydrotechnical events. In agricultural areas where the soil is vulnerable to erosion, in order to fight and prevent the development of erosion processes on slopes of up to 200 should perform tillage and seeding field crops only across a slope, as well as apply krestovanie and chemical containment areas. When the cultivation of long slopes must leave intact transverse buffer strips 3-5 m. plowing the same slopes 200 and above you must deny categorically, producing or using them are reaffirmed under orchards and vineyards.

h) In the area of distribution of gully erosion control activities should be ravine formation differently, depending on the stage of development of the ravines.

i) Based activities should be focused on the detention of water runoff and reduce the concentration of flows in the catchment area through the use of machinery mation and optionally-engineering constructions. use different ways to fight gully erosion would be of great value in the part of the foothills of the southern slope of the Greater Caucasus, where the Mingachevir reservoir.

j) Protection of soils from wind erosion should be conducted by creating forest belts and windbreaks, which is the most important factor in soil blowing, in combination with a set of special anti-irrigation agrotechnical techniques.

\section{References}

1. Aliyev GA (1959) Soil of Azerbaijan SSR, IZD vo Volobuev Vr "EN" SSR Baku.

2. Aliev BH (1999) History of reclamation science in Azerbaijan, its future development and methodology. Elm Baku pp. 112.

3. Aliev BH (1994) Irrigation Technique in Azerbaijan. Azerneshr Baku pp. 236.

4. Alekperov KA (1961) Soil erosion in Azerbaijan and the fight against it. Baku city.

5. Budagov BA (1993) Relief Azerbaijan Baku "Elm".

6. Grossgejm AA (1948) Vegetation of the Caucasus. The Moscow society of naturalists, Moscow.

7. Qashqai MA (1939) Geological and petrographic essay area mineral springs. Istisu and their geochemical characteristics.

8. Prilipko LI (1964) Forest vegetation of Azerbaijan, Baku.

9. Agriculture Balance (1969) SSR, Baku "Elm".

10. Shyhlinskij EM (2000) Climate of Azerbaijan.

11. Shyhlinskij EM (1968) Heat from Azerbaijan, Baku, Izd-vo. Azeri SSR 341: 344 .

12. Use of gis programs in research of erosion of soils in azerbaijan and determination of conditions of their protection. educational materials. The tpi in the city of falents pp. 117

13. Erosiology MN, Zaslavsky (1983) publishing house Higher School

14. AA Ibrahimov, BH Aliyev (2000) Agroecological feature of eroded soils of Azerbaijan. Materials on the study of erosion and irrigation and soil conservation in Azerbaijan. Baku.

15. SS Sobelyov (1948) The development of erosion processes on the territory of the European part of the USSR and the struggle against them. Publishing House of the USSR Academy of Sciences.

16. Исходный текст

17. Use of programs gis in research of erosion of soils in Azerbaijan and determination of conditions of their protection. educational materials. tpi in the city of falents, Poland-Project 640 / AD / 2010. p.117

\section{Your next submission with Juniper Publishers} will reach you the below assets

- Quality Editorial service

- Swift Peer Review

- Reprints availability

- E-prints Service

- Manuscript Podcast for convenient understanding

- Global attainment for your research

- Manuscript accessibility in different formats

( Pdf, E-pub, Full Text, Audio)

- Unceasing customer service

Track the below URL for one-step submission https://juniperpublishers.com/online-submission.php 